\title{
Control of fetal survival in CBA $\times$ DBA/2 mice by lymphokine therapy
}

\author{
G. Chaouat*, E. Menu*, D. A. Clark $\dagger$, M. Dy $\ddagger$, M. Minkowski $\ddagger$ and \\ T. G. Wegmann $\$$
}

*U 262 INSERM, Clinique Universitaire Baudelocque, 123 Bd de Port Royal, 75674 Paris Cedex 14, France; †McMaster University, Department of Medicine, Hamilton, Ontario, Canada L8N 3Z1; $\ddagger U 25$ INSERM, Hopital Necker, 149 rue de Sévres, 75015 Paris, France; and $\S$ Department of Immunology, University of Alberta, Edmonton, Alberta, Canada T6G $2 \mathrm{H} 7$

Summary. In this study, we examined the effect of injecting various cytokines. We report here that tumour necrosis factor (TNF) $\alpha, \gamma$-interferon and interleukin 2 (IL-2) can, in some circumstances, increase fetal resorption rates in abortionprone $(\mathrm{CBA} / \mathrm{J} \times \mathrm{DBA} / 2)$ and non-abortion prone $(\mathrm{CBA} / \mathrm{J} \times \mathrm{BALB} / \mathrm{c}, \mathrm{C} 3 \mathrm{H} \times \mathrm{DBA} / 2)$ matings: 1000 units TNF enhanced resorptions from 43 to $79 \%$ in $\mathrm{CBA} \times \mathrm{DBA} / 2$, from 7 to $89 \%$ in CBA $\times \mathrm{BALB} / \mathrm{c}$, from 5 to $47 \%$ in $\mathrm{C} 3 \mathrm{H} \times \mathrm{DBA} / 2$. The effect was both gestational age- and dose-dependent. Gamma interferon and R-IL-2 enhanced resorptions from 38 to $68 \%$ and $76 \%$ respectively in the $\mathrm{CBA} / \mathrm{J} \times \mathrm{DBA} / 2$ mating combination, whereas the rates in $\mathrm{CBA} / \mathrm{J} \times \mathrm{BALB} / \mathrm{c}$ matings were enhanced from 6 to $44 \%$ and $55 \%$. Lipopolysaccharride (LPS), which is known to lead to the release of TNF- $\alpha$, had a similar effect, leading to gestational age- and dose-dependent enhancement of resorptions up to $100 \%$.

However, cytokines of the CSF family, including IL-3 and GM-CSF, increased the chances of fetal survival when injected into abortion-prone mice, e.g. reducing resorption rates in the abortion-prone CBA $/ \mathrm{J} \times \mathrm{DBA} / 2$ mating combination from 55 to $22 \%$ (IL-3), and 47 to $8 \%$ (GM-CSF). They also increased fetal and placental weight and, in particular, expanded the spongiotrophoblast zone in the placenta. The latter observations may be due to a direct trophic influence on placental cells, perhaps through a cytokine cascade, or an indirect effect due to inhibition of natural killer (NK)-like cells, or both. Whatever the mechanism, these results may find practical application in influencing reproductive outcome in women and other species.

Keywords: abortion; mice; lymphokines; induction; treatment

\section{Introduction}

There is increasing evidence that some recurrent abortions in women might be preventable by immunization of the mother against paternal or third party alloantigens (Taylor \& Faulk, 1981; Mowbray et al., 1985). Ethical concerns limit the extent of studies on this subject in women but there now exist several models of pregnancy failure in mice and its correction by lymphocyte alloimmunization.

The best studied model is the mating of CBA females with DBA/2 males: CBA/J, but not $\mathrm{C} 3 \mathrm{H}-\mathrm{HeJ}$, females have an abnormal resorption rate when mated with DBA/2 males (Clark et al., 1980 ), but when CBA/J females are mated with $\mathrm{BALB} / \mathrm{c}$ males, the fetal resorption rate is normal (Chaouat et al., 1983). In this system, there is suggestive evidence that abortion is mediated by asialo GM1-positive natural effector cells (Chaouat et al., 1987; Baines \& de Fougerolles, 1988). If 
CBA/J females are immunized against BALB/c lymphocytes before mating, the high resorption rates in CBA/J mice mated with DBA/2 males are prevented (Chaouat et al., 1983, 1987, $1988 \mathrm{a}, \mathrm{b}, \mathrm{c}$ ) and there is no longer accumulation of asialo $\mathrm{Gm} 1+$ cells in the uterus (Gendron \& Baines, 1988). Protection against abortion can be adoptively transferred by CBA/J anti-BALB/c immune $T$ cells, or $T$ cells from the spleens of $\mathrm{CBA} / \mathrm{J}$ mice that were multiparous by repeated mating to BALB/c males (Chaouat et al., 1985). Furthermore, T cell-derived cytokines such as IL-3, GM-CSF and CSF-1 were strongly supportive of the in-vitro proliferation of placental cells (Athanassakis et al., 1987; Armstrong \& Chaouat, 1989), and, conversely, tumour necrosis factor (TNF) $-\alpha$ and $-\beta$ proved to be cytostatic for these placental cells in vitro. In addition, in-vivo depletion of $T$ cells enhanced resorption rates in CBA females mated with DBA/ 2 males as well as in the non-abortion prone CBA $\times \mathrm{BALB} / \mathrm{c}$ mating (Chaouat et al., 1988a). Further support for a trophic role of activated $\mathrm{T}$ cells in vivo came from the observation that depletion of $\mathrm{T}$ cells in the autoimmune MRL lpr/lpr strain corrected placental hypertrophy and placental phagocytic activity was then normal. This observation was corroborated by the finding that transfer of cells from $M R L$ lpr/lpr mice into $\mathrm{H}-2 \mathrm{k}$-compatible CBA/J females prevented the CBA $\times \mathrm{DBA} / 2$ pregnancy from showing increased fetal resorption (Chaouat et al., 1988a, b). Since these mice are known to produce excess IL-3, and autoantibodies with IL-3-like activity, and based on the aforementioned evidence, we decided to test directly various lymphokines, all of them products from activated $\mathrm{T}$ cells, for their effect on fetal resorption in CBA/J mice mated with DBA/2 males.

\section{Materials and Methods}

Mice. CBA/J mice were obtained from Iffa Credo (L'Arbresle, France) at the age of 8 weeks. They were kept for another 2 weeks in our animal facility before mating. The day of observing a vaginal plug was termed Day 0.5 of pregnancy.

Since the rate of resorption increases with ageing or environmental conditions (Chaouat et al., 1987, 1988a; Hamilton \& Hamilton, 1987) mice were in some cases aged a further 5 weeks before mating in a conventional room where abortions were known to be higher (Chaouat et al., 1987, 1988a) than in the gnotobiotic facility. C3H/HeJ, C57BL/6, DBA/2 and BALB/c.J mice were obtained from the IRSC, Villejuif, France, at the age of 8 weeks, and also maintained for 2 weeks before use.

For experiments performed in Canada 6-8-week-old CBA/J mice were obtained from the Jackson Laboratory (Bar Harbor, ME, USA) and maintained until 12 weeks of age when they were mated.

Fetal resorptions were assessed on Day 14.5 of pregnancy, unless otherwise stated. In some experiments, animals were allowed to deliver to confirm the anti-abortive effect by direct assessment of viable offspring. This technique suffers from the fact that some pregnant mothers eat their offspring and placentae immediately after birth: the mean litter size was therefore determined on Day 1, as the 'surviving' litter size. Animals which had clearly eaten their progeny were excluded from the experiment. There was no indication that any treatment which we employed had an influence on this type of behaviour.

Lymphokines and reagents. Purified GM CSF was obtained from the P338 D1 cell line as described by Dy et al. (1987). Recombinant murine GM-CSF was purchased from Genzyme Inc. (Boston, MA, USA) directly or via Tebu France (Le Perray, Yvelines, France). Recombinant human GM-CSF (produced in CHO cells) was a kind gift from the Genetics Institute, Boston, MA, USA. All recombinant materials were purified to homogeneity by the manufacturers, and did not contain other lymphokines or lipopolysaccharide (LPS) that might interfere with the assay. Lipopolysaccharide (Difco, via Sigma France, itself via OSI France, Paris, France) extracted from Salmonella enteritidis was from a batch pretested in various LPS and LPS/TNF assays, and was a kind gift of Dr M. Parand, Institut Biomédical des Cordeliers, Paris, France. Recombinant human TNF- $\alpha$, murine and human IL-2, and murine $\gamma$-interferon were kindly donated by Dr J. Wietzerbin, Institut Curie, Paris, France. Rabbit polyclonal antibody against murine GM-CSF was kindly donated by the Glaxo Institute for Molecular Biology, Geneva, Switzerland. Purified IL-3 was prepared from the WEHI cell line as described by Dy et al. (1987).

LPS was injected i.v. at $1 \mu \mathrm{g}$ on Day 7 or 12 , or $3 \mu \mathrm{g}$ on Day 15. Mice were killed on Day 12 when injection was performed on Day 7, on Day 16 for injection performed on Day 12, or Day 19 for injection performed on Day 15. For TNF experiments, each group was injected i.v. with 1000 units of human recombinant TNF- $\alpha$ or saline on Day 7.5 of gestation, and mice were examined on Day 14.5 for fetal resorption. Alternatively, 1000, 2000 or 3000 units TNF were injected on various days of gestation and mice were checked on Day 12 (injections until Day 10.5) or 17 (injection on Day 13.5) or 19.5 (just before parturition) for injection on Day 17.5. Gamma interferon was given at 1500 units i.p. on Day 7.5 of gestation, and R-IL-2 was given at 2000 units i.p. on Days $6.5,8.5$ and 10.5 of gestation. Mice were killed on Day 14.5. Other mice received 600 units IL-3 i.p. on Day 6.5, 8.5 or 10.5 and were killed on Day 14.5. 
GM-CSF was injected i.p. as (a) $400 \mathrm{HCSF}$ units in $0.2 \mathrm{ml}$ saline on Days $6.5,8.5$ or 10.5 or (b) $200 \mathrm{HCSF}$ units in phosphate-buffered saline (PBS) on Day 6.5, $8 \cdot 5$ or $10 \cdot 5$.

For dose-response experiments $200,400,1000$ or 2500 units of GM-CSF were injected i.p. in PBS. In some cases, GM-CSF was dissolved in medium RPMI 1640 before injection. For the experiments that were conducted in Canada with recombinant human GM-CSF (Genetic Institute) and murine GM-CSF (Genzyme), a single dose of 200 units was injected on Day 7.5 of pregnancy.

Spongiotrophoblast width. To estimate spongiotrophoblast width (Table 7), spongiotrophoblasts were sliced from fresh placentae with a surgical lance, then snap-frozen and measured by calipers in $\mathrm{mm}$. The labyrinthine zone was also measured but the enlargement was not statistically significant in the limits of these experiments (number of placentae studied) and the data are therefore not shown.

Statistics. Student's $t$ tests (placental width, fetal and placental weights) and $\chi^{2}$ analysis ( $\%$ resorptions) were performed to test the significance of treatment effects.

\section{Results}

\section{Negative effects on pregnancy outcome}

LPS from Salmonella enteritidis has been shown to induce complete fetal death in several strains of mice at a dose of $1 \mu \mathrm{g}$ per mouse when given i.v. on Day 7.5 or Day 12.5 (a dose of $3 \mu \mathrm{g}$ per mouse is required for abortion on Day 15-18) (Parand \& Chedid, 1964), irrespective of the strain.

Table 1 shows typical experiments that confirm these data for various mating combinations of mice which are not abortion prone, as well as in the CBA $\times \mathrm{DBA} / 2$ abortion-prone mice.

Direct measurement of TNF- $\alpha$ in the decidua confirmed that abortion was correlated with an enhancement of TNF levels (data not shown, and Chaouat et al., 1990), in agreement with previous data (Parand \& Chedid, 1964; Parand, 1987; Gendron et al., 1989).

Table 1. Induction of fetal resorption (\%, with no. viable, no. resorbing in parentheses) by lipopolysaccharide in mice of various mating combinations injected on Day 7,12 or 15

\begin{tabular}{|c|c|c|c|c|}
\hline \multirow{3}{*}{$\begin{array}{c}\text { Mating } \\
\text { combination }\end{array}$} & \multirow{3}{*}{$\begin{array}{l}\text { Control } \\
\text { mice }\end{array}$} & \multicolumn{3}{|c|}{ Treated mice* } \\
\hline & & \multicolumn{2}{|c|}{$1 \mu \mathrm{g}$ i.v. } & \multirow{2}{*}{$\frac{3 \mu \mathrm{g} \text { i.v. }}{\text { Day } 15}$} \\
\hline & & Day 7 & Day 12 & \\
\hline $\mathrm{C} 3 \mathrm{H} \times \mathrm{BALB} / \mathrm{c}$ & $6(43,2)$ & $98(1,45)$ & $100(0,48)$ & $91(4,41)$ \\
\hline $\mathrm{C} 57 \mathrm{BL} / 6 \times \mathrm{DBA} / 2$ & $6(44,3)$ & $96(1,42)$ & $98(1,39)$ & $95(2,40)$ \\
\hline $\mathrm{C} 57 \mathrm{BL} / 6 \times \mathrm{BALB} / \mathrm{c}$ & $8(47,4)$ & $100(0,48)$ & $96(2,53)$ & $98(1,50)$ \\
\hline $\mathrm{CBA} / \mathrm{J} \times \mathrm{BALB} / \mathrm{c}$ & $10(45,4)$ & $100(0,51)$ & $100(0,48)$ & $92(4,48)$ \\
\hline $\mathrm{CBA} / \mathrm{J} \times \mathrm{DBA} / 2$ & $38(17,28)$ & $100(0,45)$ & $100(0,49)$ & $100(0,43)$ \\
\hline $\mathrm{C} 3 \mathrm{H} \times \mathrm{DBA} / 2$ & $5(39,2)$ & $100(0,39)$ & $100(0,40)$ & $100(0,45)$ \\
\hline
\end{tabular}

When 1000 units of recombinant human TNF- $\alpha$ were injected on Day 7.5 i.p., a significant increase in fetal resorption rates was observed in $\mathrm{CBA} \times \mathrm{DBA} / 2$ mice as well as in the nonabortion-prone $\mathrm{CBA} \times \mathrm{BALB} / \mathrm{c}$ and $\mathrm{C} 3 \mathrm{H} \times \mathrm{DBA} / 2$ combinations. The effect was still significant when TNF- $\alpha$ was given on Days 9 and 10. However, to obtain a comparable level of fetal resorption rate, a higher dose of TNF was required on Days 13 and 17, although 1000 units significantly enhanced the fetal resorption rates above background levels (Table 2).

Poly(I).Poly(C12U), an inducer of $\gamma$-interferon production and an activator of natural killer cells (NKs) and lymphokine-activated killer cells (LAKCs), is known to increase fetal resorption rates (Baines \& de Fougerolles, 1988; Chaouat et al. 1988a, 1989a, b, c; R. Kinsky, G, Lepage, 


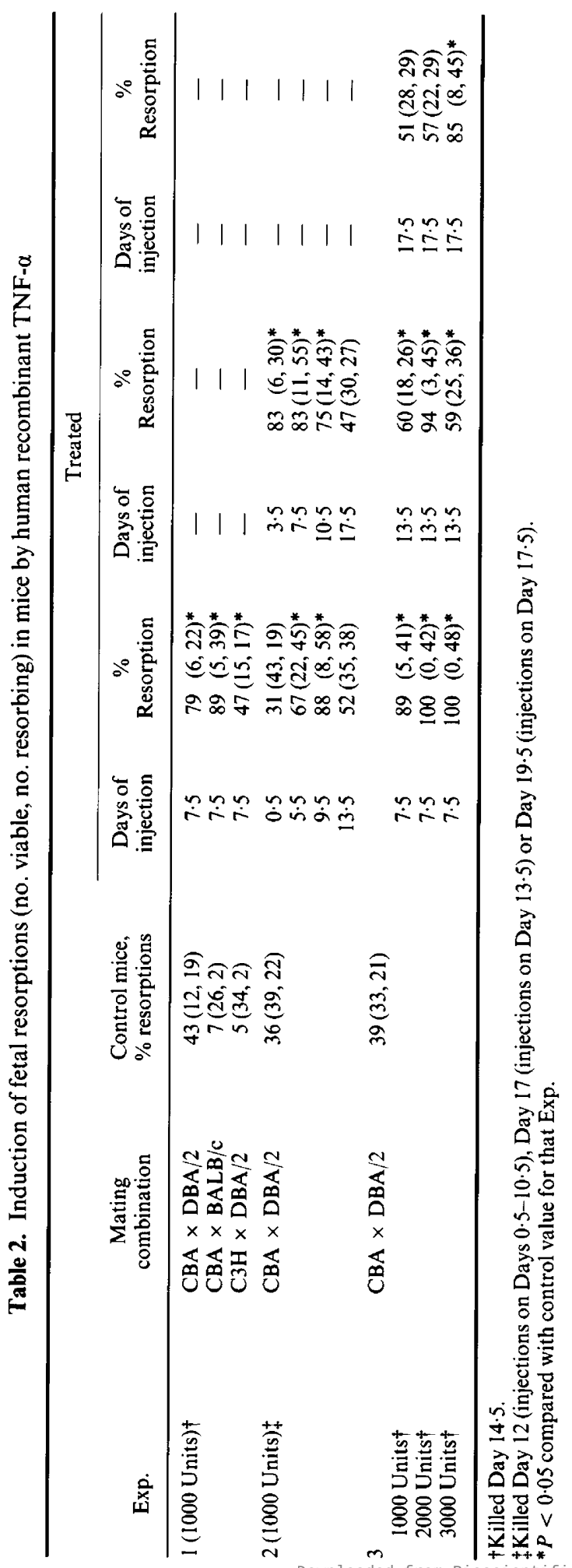


M. N. Thang \& G. Chaouat, unpublished). We therefore also tested the effects of treatment with $\gamma$-interferon, and recombinant murine IL-2, a LAKCs and NK cell activator. Both treatments enhanced fetal resorption in the $\mathrm{CBA} \times \mathrm{DBA} / 2$ and $\mathrm{CBA} \times \mathrm{BALB} / \mathrm{c}$ mating combinations (Table 3).

Table 3. Enhancement of fetal resorptions (\%, no. viable, no. resorbing) by murine recombinant $\gamma$-interferon (1500 Units on Day $7 \cdot 5)$ and murine recombinant IL-2 (2000 Units on Days 6.5, 8.5 and 10.5)

\begin{tabular}{|c|c|c|c|}
\hline \multirow{2}{*}{$\begin{array}{c}\text { Mating } \\
\text { combination }\end{array}$} & \multirow{2}{*}{$\begin{array}{l}\text { Control } \\
\text { mice }\end{array}$} & \multicolumn{2}{|c|}{ Treated mice $\dagger$} \\
\hline & & $\gamma$-Interferon & IL-2 \\
\hline $\mathrm{CBA} / \mathrm{J} \times \mathrm{DBA} / 2$ & $38 \%(18,11)$ & $68 \%(8,17)^{*}$ & $76 \%(8,17)^{*}$ \\
\hline $\mathrm{CBA} / \mathrm{J} \times \mathrm{BALB} / \mathrm{c}$ & $6 \%(31,2)$ & $44 \%(18,14)^{*}$ & $55 \%(15 / 18)^{*}$ \\
\hline
\end{tabular}

$\dagger$ Killed on Day 14.

${ }^{*} P<0.05$ compared with control.

\section{Positive effects on pregnancy outcome}

When IL-3 was injected i.p. fetal resorption rates were decreased in CBA $\times \mathrm{DBA} / 2$ pregnancies whereas in the same experiment treatment with LPS or recombinant human TNF had the opposite effect (Table 4).

Table 4. Reduction of CBA $\times \mathrm{DBA} / 2$ fetal resorption by murine IL-3 from WEHI cells

\begin{tabular}{|c|c|c|c|c|c|c|c|}
\hline \multirow[b]{2}{*}{ Exp. } & \multicolumn{3}{|c|}{ Control mice } & \multicolumn{4}{|c|}{ Treated mice $\dagger$} \\
\hline & $\%$ Resorbing & $\begin{array}{c}\text { Placental } \\
\text { wt (mg) }\end{array}$ & $\begin{array}{c}\text { Fetal } \\
\text { wt (mg) }\end{array}$ & Treatment & $\%$ Resorbing & $\begin{array}{l}\text { Placental } \\
\text { wt (mg) }\end{array}$ & $\begin{array}{c}\text { Fetal } \\
\text { wt (mg) }\end{array}$ \\
\hline 1 & $52(14,13)$ & 102 & 121 & IL-3‡ & $28(15,6)^{*}$ & $125^{*}$ & $141^{*}$ \\
\hline 2 & $55(17,21)$ & - & - & IL-3† & $22(25,7)^{*}$ & - & - \\
\hline \multirow[t]{4}{*}{3} & $46(22,19)$ & - & - & IL-3† & $19(30,7)^{*}$ & - & - \\
\hline & & & & LPS $\S$ & $88 \quad(3,22)^{*}$ & - & - \\
\hline & & & & H-rTNF- $\alpha$ ๆ & $93(2,27)^{*}$ & - & - \\
\hline & & & & PBS & $54(18,21)$ & - & - \\
\hline
\end{tabular}

†Killed on Day $14 \cdot 5$.

$\$ 600$ Units on Days 6.5, 8.5 and $10 \cdot 5$.

$\$ 0.1 \mu \mathrm{g}$ in PBS on Days $6.5,8.5$ and 10.5 .

T500 Units on Days 6.5, 8.5 and 10.5.

${ }^{*} P<0.05$ compared with controls.

Treatment with 200 or 400 units of purified natural GM-CSF decreased CBA $\times$ DBA $/ 2$ fetal resorption rates (Table 5). When different doses of GM-CSF were tested, dosages of $>1000$ Units per injection were ineffective (Table 5). In fact, $3 \times 2500$ HCSF units sometimes enhanced fetal resorptions, although most often the enhancement was not significant, and at best $P$ values were $<0.02$ (data not shown).

Treatment with recombinant murine GM-CSF (Genzyme) given on the same schedule at low doses was also protective (Table 6).

Both forms of murine GM-CSF not only affected fetal survival, but also enhanced placental (and fetal) weights (Tables 5 and 6). The enhancement appeared to depend markedly upon additional spongiotrophoblast width as a result of treatment (see Table 6). No significant size enhancement was traced in the labyrinth (data not shown). 


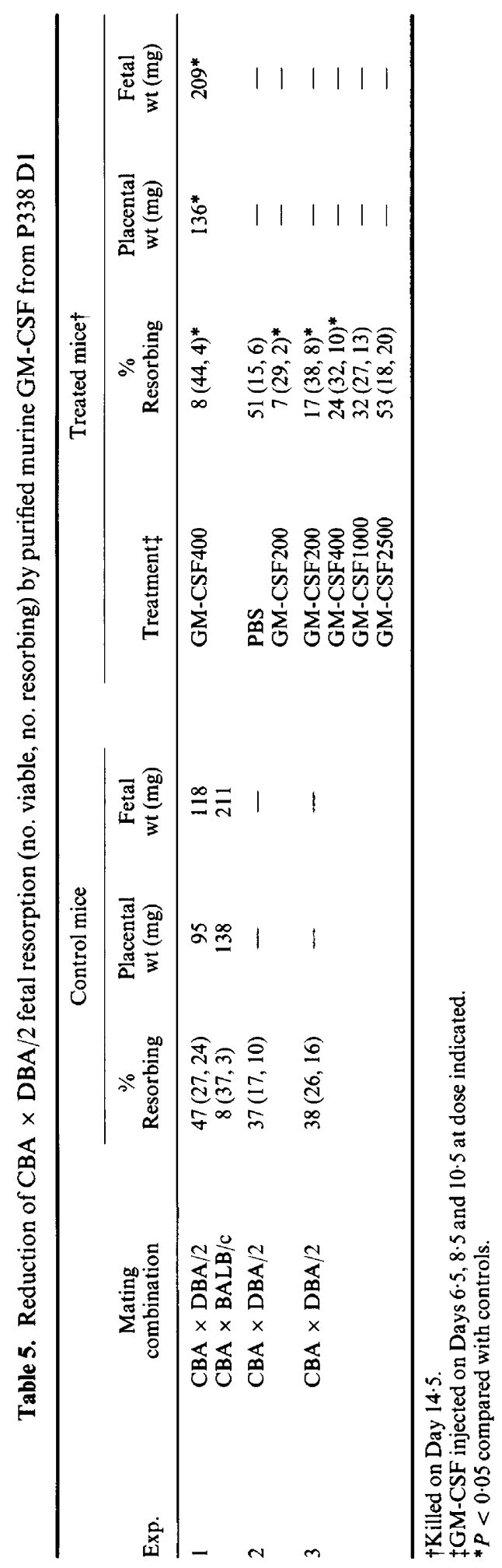




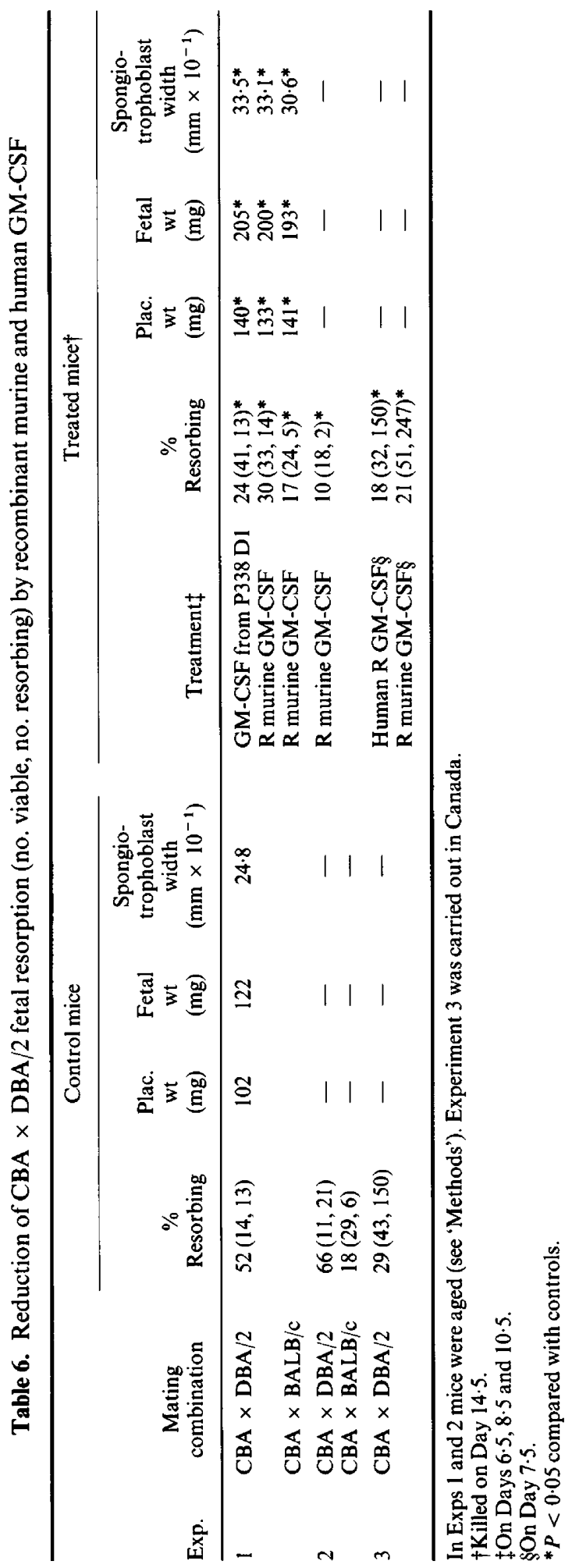


Similar experiments conducted in Canada used a recombinant human GM-CSF (Genetic Institute) and the same murine GM-CSF (Genzyme), but the control levels of resorption were much lower. A single dose of 200 units of either form of GM-CSF on Day 7.5 of pregnancy was minimally effective (Table 6). The murine GM-CSF stimulated placental cell growth in vitro but the human recombinant GM-CSF was inactive in this regard (data not shown, and Clark et al., 1990). High doses of the human GM-CSF (10000-30000 units/mouse) were ineffective, similar to the data shown in Table 5.

Since P 338 D1 purified material contained traces of IL-1 and IL-3, it was important to ascertain that the effects of $\mathrm{P} 338 \mathrm{Dl}$ supernatant and recombinant GM-CSF were mediated by GM-CSF itself and not by some contaminant in the preparation. Recombinant murine GM-CSF, or P $338 \mathrm{D} 1$ material, was passed through a column containing normal rabbit serum coupled to CNBr-activated Sepharose 4B (Pharmacia, Pharmacia-LKB, Les Ulis, France) or similarly prepared rabbit anti-murine GM-CSF. The specific antiserum retained the fetal protective effect, while the control column eluant did not (Table 7).

Table 7. Removal of reduction of CBA $\times \mathrm{DBA} / 2$ fetal resorption (no. viable, no. resorbing) by recombinant murine GM-CSF following adsorption with anti-GM-CSF antiserum coupled on Sepharose 4B

\begin{tabular}{lcll}
\hline \multirow{2}{*}{$\begin{array}{c}\text { Mating } \\
\text { combination }\end{array}$} & $\begin{array}{c}\text { Control } \\
\text { mice, } \\
\% \text { resorbing }\end{array}$ & \multicolumn{1}{c}{ Treated micet } \\
\cline { 3 - 4 } CBA $\times$ DBA $/ 2$ & $42(30,22)$ & Treatment & GM-CSF \\
& & $\begin{array}{l}\text { GM-CSF + antiserum } \\
\text { GM-CSF on control column }\end{array}$ & $\begin{array}{l}14(47,8)^{*} \\
24(29,18)\end{array}$ \\
$\mathrm{CBA} \times \mathrm{BALB} / \mathrm{c}$ & $7(36,3)^{*}$ & & \\
\hline
\end{tabular}

$\dagger$ Killed on Day $14 \cdot 5$.

${ }^{*} P<0.05$ compared with $\mathrm{CBA} \times \mathrm{DBA} / 2$ control.

\section{Discussion}

The results presented in this paper clearly demonstrate that pregnancy outcome can be positively or negatively regulated by injecting lymphokines directly into pregnant females. This raises the question of the mechanisms involved in this regulation. The trophoblast is resistant to cellmediated lysis by normal killer cells (cytotoxic T lymphocytes, CTLs) or natural killer cells (NK), but is sensitive to lysis by lymphokine-activated killer cells (LAKC)s or CTLs obtained from a mixed lymphocyte reaction performed in a culture medium (Opti-MEM, Gibco) (a derivative of Minimal Essential Medium (MEM)) which is optimized especially for LAKCs culture generation, and which yields from a mixed lymphocyte culture/reaction CTLs endowed with LAKC-like killing activity (Gendron \& Baines, 1988; Drake \& Head, 1989). The peri-implantation embryo is surrounded by NK cells (Croy et al., 1987) and some non-lymphoid cells at the implantation site, such as granulated metrial gland cells, have some NK-like activity, exerting cytostatic effects on 3.5-day blastocysts and 6.5-day embryonic tissue of mice (Croy \& Kassouf, 1989). It is tempting to speculate that they could themselves be regulated by lymphokines, and secrete some lymphokines, and thus be involved in the control of placental growth (Wegmann et al., 1989.

Furthermore, it has been shown that spontaneous abortion rates in the abortion-prone $\mathrm{CBA} \times \mathrm{DBA} / 2$ mouse system correlate with the local infiltration of asialo GM 1-positive cells (Gendron \& Baines, 1988). Indeed, it has been shown that embryos are first infiltrated by cells with NK-like activity, and only thereafter by some cytotoxic T lymphocytes (Chaouat, 1986). Trophoblast cells themselves are not sensitive to NK cell lysis, but human and mouse embryonic 
fibroblasts, for example, are. Activated NKs and LAKCs are therefore a probable threat to fetal survival. It ensues that the local $T$ cell activation/expansion by interleukin- 2 and interleukin- $4,-5$ and -6 , the activation/enhancement of NK lytic activity, also mostly by these lymphokines, and the differentiation and expansion in the decidua of LAKCs needs to be down-regulated at the feto-maternal interface for fetal survival. It is achieved in the decidua by decidual suppressor cells that secrete a TGF- $\beta$-2-like molecule (Clark et al., 1988) and a placenta-derived factor which has immunosuppressive activity coupled to fibroblast growth factor properties, and other TGF- $\beta$ 2 -like properties (Chaouat et al., 1990). (It is worth recalling that TGF- $\beta 2$ can block the proliferation/activation of the aforementioned lymphocyte subsets and, in addition, exert direct protective effects on targets of products from activated T and NK cells, exactly as does TNF, when tested on such targets as murine embryonic fibroblasts, or the murine malignant fibroblastic cell line, L929.) Although placenta-mediated suppression is deficient in resorbing animals on Day 11 (Chaouat et al., 1985), no such difference is seen at earlier stages, whereas there is a clear correlation between the level of decidual suppression at the implantation site and subsequent fetal resorption (Clark et al., 1987). It is therefore possible that a defect in local suppression would result in too high a level of local NK-cell activity, and recruitment and/or activation of LAKCs, thus leading to embryo demise.

Environmental factors are involved in the CBA $\times$ DBA $/ 2$ resorption models (Hamilton \& Hamilton, 1987), most likely microbial in nature and probably resulting in local activation of non-specific effectors. IL-2 can lead to NK-cell differentiation into LAKCs, and it is likely that injections of excess IL-2 by-pass local active suppression and trigger such detrimental activation/ differentiation. Our data are in keeping with those of Tezabwala et al. (1989), although in our hands we need to inject higher doses than they do to obtain induction of abortion. Such discrepancy is most probably due to environmental conditions, as discussed below for 'basal' resorption rates.

NK activation can be directly achieved in pregnant females by Poly(I).Poly(C12)U injection. Injection of spleen cells from animals Poly(I).Poly(C12)U into CBA/J females, or direct treatment of these, elicits abortion (Baines \& de Fougerolles, 1988; Chaouat et al., 1988c, d, 1989a, b). Such effects are seen not only in $\mathrm{CBA} / \mathrm{J}$, but also in $\mathrm{BALB} / \mathrm{c}, \mathrm{C} 57 \mathrm{BL} / 6 \mathrm{mice}$, which are non-resorptionprone strains (Chaouat et al., 1989b, c, 1990; unpublished data). This paper demonstrates that the effects on pregnancy outcome of such activated NK cell-enriched cellular transfer can be mimicked by injecting TNF and $\gamma$-interferon, which are products of such activation. Their action could be cytostatic for placental cells, as demonstrated in vitro, or directly cytotoxic for non-trophoblastic components of the placenta (such an effect is highly likely in the case of embryonic fibroblasts), whereas IL-2 is likely to act by activating LAKCs themselves. In addition, TNF could act by causing local necrosis as a consequence of its action on the blood vessels that penetrate the placenta.

TNF could be produced as a result of local triggering of decidual T cells and NK cells, as well as macrophages, as a bystander effect of infection. LPS would merely mimic the infection-related event. Such a mechanism would account for environmental or ageing effects in the CBA $/ J \times D B A / 2$ system (Hamilton \& Hamilton, 1987; Chaouat et al., 1986, 1988b). We took advantage of such effects to enhance the basal resorption rates in our CBA/J mice by letting them age for the R GMCSF experiments. This effect accounts for most of the variation one can observe between our tables, since mice of the same age in the same room had no gross (statistically significant) variations in resorption rates throughout the year.

The effect of IL-3 is more complicated to explain. Such a therapeutic effect does not necessarily represent a physiologically significant event, because IL-3 has not yet been demonstrated at the maternal-fetal interface, although one report describes the presence of IL-3 mRNA in the decidua (Shorter et al., 1989). Nevertheless, placental cells appear to be responsive in vitro to all members of the CSF family tested so far, and GM-CSF itself has been shown to have direct trophic effects on outgrowth of pure ectoplacental cone trophoblast (Armstrong \& Chaouat, 1989). 
GM-CSF can also be released from the decidua. The doses of recombinant murine GM-CSF that we inject are far too low to act directly on placental cell growth in the mouse, as deduced from in-vitro titration curves. Furthermore, human GM-CSF protects against high resorption rates in the murine $\mathrm{CBA} \times \mathrm{DBA} / 2$ matings. This lymphokine has no direct effect on murine placental cell growth in vitro, and human GM-CSF does not sustain the growth or promote colony formation by mouse progenitor cells. The involvement on placental or decidual cells of a new type of CSF receptor, able to mediate activities of this lymphokine on non-lymphoid progenitor, with no species restriction, has been suggested (G. Vadas, unpublished data) but not yet proved. The demonstration of GM-CSF receptor on human trophoblast, possibly a new receptor, could clarify this issue (Uzumaki et al., 1989). In the meantime, to explain these effects, we suggest at least four possible mechanisms, which are not necessarily mutually exclusive, and deserve consideration for future experimentation. (1) GM-CSF could trigger local release of CSF1 or more GM-CSF by macrophages or other cells leading to a direct or indirect trophic effect. (2) CSF1 might be released by placental cells themselves in response to low doses of GM-CSF in a paracrine loop, and high doses would result in a negative feed back. (3) Since some $T$ cell lymphomas have been shown to secrete CSF1 (Pralloran et al., 1989), and since HILDA/LIF, a product of CD4 and CD8 T cells has a direct trophic effect on extra somatic cells (Moreau et al., 1988), the possibility that GM-CSF might have an effect on such a $T$ cell subset is worthy of further examination. (4) GM-CSF is involved with interferon in natural suppressor mechanisms (Cleveland et al., 1988), which share a certain number of properties with decidua and placenta-associated suppression, and IL-3 can abrogate LAKC activation/generation in the human (Gallagher et al., 1988). Using the measurement of TNF- $\alpha$ to assess cytotoxicity of decidual supernatant on the L929 malignant murine fibroblast cell line, a classical test of TNF activity, we observed an inverse correlation in the CBA $\times$ DBA/2 system between TNF and GM-CSF titres (assessed as HCSF activity) in the decidua (Chaouat et al., 1990). Although L929 is sensitive to TNF- $\alpha$ and $-\beta$, as well as the cytotoxic effects of other lymphokines, it is tempting to speculate that placental growth is under the control of decidual stop signals, amongst which TNF production by activated natural killer cells and lymphokine-activated killer cells, as well as granulated metrial gland cells, could be an element. Down-regulation by members of the CSF family of lymphokines of TNF production would result in enhanced placental growth, which would be functionally indistinguishable from a direct trophic effect, and may operate in parallel with it.

Whatever the mechanism(s) involved the results described in this paper indicate a direct influence of lymphokines on reproductive outcome in vivo.

This work was supported by the ARC, the Fondation pour la Recherche médicale, the Edmond de Rothschild Fondation, Ligue National contre le Cancer, and an INSERM Réseau d'études et de Recherches Cliniques (Reseau No 4480 06).

We thank J. Manuel and D. Banwatt (McMaster University, Department of Medicine) for help with some of the experiments.

\section{References}

Armstrong, D.T.A. \& Chaouat, G. (1989) Effects of lymphokines and immune complexes on murine placental cell growth in vitro. Biol. Reprod. 40, $400-406$.

Athanassakis, I., Bleackley, R.C., Paetkau, V., Guilbert, L., Barr, P.J. \& Wegmann, T.G. (1987) The immunostimulatory effects of $T$ cells and $T$ cell lymphokines on murine fetally derived placental cells. J. Immunol. $138,37-44$.

Baines, M. \& de Fougerolles, R. (1988) Modulation of
Natural Killer activity influences resorption rates in $\mathrm{CBA} \times \mathrm{DBA} / 2$ matings. J. Reprod. Immunol. 11, $147-153$.

Chaouat, G., Kiger, N. \& Wegmann, T.G. (1983) Vaccination against spontaneous abortion in mice. $J$. Reprod. Immunol. 8, 389-394.

Chaouat, G., Kolb, J.P., Kiger, N., Stanislawski, M. \& Wegmann, T.G. (1985) Immunological concomitants of vaccination against abortion in mice. J. Immunol. $134,1594-1598$. 
Chaouat, G. (1986) Placental infiltration of resorbing CBA $\times$ DBA $/ 2$ embryos. $J$. Reprod. Immunol., Suppl 1, 134, Abstr.

Chaouat, G., Lankar, D., Kolb, J.P. \& Clark, D.A. (1987) 2 modeles d'avortements d'origine immunitaire chez la souris de laboratoire: mecanismes abortifs, modalites et mecanismes du traitement par l'immunisation contre un male relie ou non relie suivant les differences antigeniques pére mére. In Immunologie de la Relation feto-maternelle (Colloq. INSERM No. 154), pp. 243-255. Ed. G. Chaouat. INSERM, Paris.

Chaouat, G., Menu, E., Athanassakis, I. \& Wegmann, T.G. (1988a) Maternal T Cells regulate placental size and fetal survival. Regional Immunology 1, 143-148.

Chaouat, G., Clark, D.A. \& Wegmann, T.G. (1988b) Genetics aspects of the CBA/J $\times$ DBA $/ 2 J$ and $\mathrm{B} 10 \times \mathrm{B} 10$.A models of murine spontaneous abortions and prevention of leukocyte immunisation. In Early Pregnancy Loss. Mechanisms and Treatment, pp. 89-105. Eds W. R. Allen, D. A. Clark, T. J. Gill III, J. F. Mowbray \& W. R. Robertson. RCOG Press, London.

Chaouat, G., Menu, E., Bustany, P., Rebut-Bonneton, C. \& Wegmann, T.G. (1988c) Role du placenta dans le maintien de l'allogreffe fetale. Reprod., Nutr. Develop. 28, 1587-1588.

Chaouat, G., Menu, E., Wegmann, T.G., Clark, D.A., Minkowski, M., Dy, M. \& Thang, M.N. (1988d) Explications actuelles du maintien de l'allogreffe fetale et hypothéses de travail sur le mécanisme d'effet des vaccins antiavortifs (Modéles murins). Contraception Fertilité Sexualité 17, 57-59.

Chaouat, G., Szekeres-Bartho, J., Menu, E., Kinsky, R., Thang, M.N., Dy, M. \& Minkowski, M. (1989b) Placental interactions with maternal immune system. In Experimental Models in Obstetrics and Gynaecology. Ed. C. Romanini. Parthenon Publishing Ltd, London. In Press.

Chaouat, G., Menu, E., Kinsky, R., Dy, M., Minkowski, M., Delage, G., Thang, M.N., Clark, D.A., Wegmann, T.G. \& Szekeres-Bartho, J. (1989c) Lymphokines and non specific cellular lytic effectors at the feto maternal interface affect placental size and survival. In Reproductive Immunology, 1989. Elsevier, Amsterdam. In Press.

Chaouat, G., Menu, E., Szekeres-Bartho, J., RebutBonneton, C., Bustany, P., Kinsky, R., Dy, M., Minkowski, M., Clark, D.A. \& Wegmann, T.G. (1990) Immunological and endocrinological factors that contribute to successful pregnancy. In Molecular and Cellular Immunology of the Feto-maternal Interface (in press). Eds T. G. Wegmann \& T. J. Gill III. Oxford University Press.

Clark, D.A., McDermott, M. \& Sczewzuk, M.R. (1980) Impairment of host versus graft reaction in pregnant mice: (II) Selective suppression of Cytotoxic cell generation correlates with soluble suppressor activity and successful allogeneic pregnancy. Cell. Immunol. 52, 106-118.

Clark, D.A., Kiger, N., Guennet, J.L. \& Chaouat, G. (1987) Local active suppression and successful vaccination against spontaneous abortion in CBA/J mice. J. Reprod. Immunol. 10, 79-86.

Clark, D.A., Falbo, M., Bruce-Rowley, R., Banwatt, D. \& Stedronska-Clark, J. (1988) Active suppression of host versus graft reaction in pregnant mice. (IX) Soluble suppressor activity obtained from allopregnant mouse decidua that blocks the cytolytic effector response is related to TGF Beta. J. Immunol. 141, 3833-3841.

Clark, D.A., Head, J.R., Drake, B., Fulop, G., Brierley, J., Manuel, J., Barwatt, D. \& Chaouat, G. (1990) Role of a factor related to transforming growth factor beta 2 in successful pregnancy. In Molecular and Cellular Immunology of the Feto-maternal Interface (in press). Eds T. G. Wegmann \& T. J. Gill III. Oxford University Press.

Cleveland, M.G., Lane, R.G. \& Klimpel, G.R. (1988) Spontaneous Interferon Beta production. A common feature of Natural Suppressor Systems. J. Immunol. 141, 2043-2048.

Croy, B.A. \& Kassouf, S.A. (1989) Evaluation of the murine metrial gland for immunological function. $J$. Reprod. Immunol. 15, 51-71.

Croy, B.A., Wood, W. \& King, G.J. (1987) Evaluation of intrauterine immune suppression during pregnancy in a species with epitheliochorial placentation. $J$. Immunol. 139, 1088-1095.

Drake, B.L. \& Head, J.R. (1988) Murine trophoblast cells are susceptible to Lymphokine Activated killer (LAK) cell lysis. Am. J. Reprod. Immunol. 16, 114, Abstr.

Drake, B.L. \& Head, J.R. (1989) Murine trophoblast cells can be killed by allospecific cytototoxic $T$ lymphocytes generated in Gibco OPTI MEM medium. J. Reprod. Immunol. 15, 71-77.

Dy, M., Schneider, E., Gastinel, L.N., Aufray, C., Mermod, J.J. \& Hamburger, J. (1987) Histamine Colony Stimulating Factor (HCSF) and GranulocyteMacrophage Colony Stimulating Factor (GM-CSF) activities are borne by the same molecule. Eur. $J$. Immunol. 17, 1243-1247.

Gallagher, G., Wilcox, F. \& Al-Azzawi, F. (1988) Interleukin 3 and Interleukin 4 each strongly suppress induction and function of human LAK cells. Clin. exp. Immunol. 74, 166-171.

Gendron, R.L. \& Baines, M. (1988) Infiltrating decidual Natural Killer cells are associated with spontaneous abortion in mice. Cell. Immunol. 113, 261-265.

Gendron, R.L., Nestel, F.P., Lapp, W.S. \& Baines, M.G. (1989) Lipopolysaccharide induced fetal resorption involves embryo associated production of Tumor Necrosis Factor. Proc. 7th Int. Congr. Immunol., Berlin, Abstr. 118-017.

Hamilton, M.S. \& Hamilton, B.L. (1987) Environmental influences on immunologically associated recurrent spontaneous abortion in CBA/J mice. J. Reprod. Immunol. 11, 237-241.

Mowbray, J.F., Lidell, H., Underwood, J.L., Gibins, S.C., Reginald, P.W. \& Beard, R.W. (1985) Controlled trial of treatment of recurrent spontaneous abortions by immunisation with paternal cells. Lancet i, 941-943.

Parand, M. (1987) Role of TNF in non specific stimulation of mouse resistance to infection. Immunobiology 175 (1/2), 26, Abstr.

Parand, M. \& Chedid, L. (1964) Protective effects of chlorpromazine against endotoxin induced abortion. Proc. Soc. exp. Biol. Med. 116, 906-915.

Downloaded from Bioscientifica.com at 04/26/2023 11:33:50AM 
Moreau, J.F., Donaldson, D.D., Bennet, F., Witek Giannotti, J., Clark, S.C. \& Wong, G.G. (1988) Leukemia inhibitory factor is identical to the myeloid growth factor for human interleukin for DA cells. Nature, Lond. 336, 6200, 690-692.

Pralloran, V., Gascan, H., Boursier, M.C. \& Soulillou, J.P. (1989) Sécrétion de M-CSF/CSF/1 par un lymphome T. Proc. French Soc. Immunol., Nantes p. 49, Abstr.

Shorter, S.C., Vince, G.S. \& Starkey, P.M. (1989) The identification of mRNA for the IL-3 related cytokines in placental and decidual tissues. Proc. 3rd Mtg Eur. Placenta Group. Eds L. Cedard, G. Chaouat, J. C. Challier \& C. Neismann. INSERM, Paris. In press.

Taylor, C. \& Faulk, W.P. (1981) Prevention of recurrent spontaneous abortions with leukocyte transfusion. Lancet ii, 68-70.
Tezabwala, B.U., Johnson, P.M. \& Rees, R.C. (1989) Inhibition of pregnancy viability in mice following IL-2 administration. Immunology 67, 115-120.

Uzumaki, H., Okabe, T., Sasaki, N., Hagiwara, K., Takaku, F., Tobita, M., Yasukawa, K., Ito, S. \& Umezawa, Y. (1989) Identification and characterisation of receptors for granulocyte colony-stimulating factor on human placenta and trophoblastic cells. Proc. natn. Acad. Sci. USA. 86, 9323-9326.

Wegmann, T.G., Athanassakis, I., Guilbert, L., Branch, D., Dy, M., Menu, E. \& Chaouat, G. (1989) The role of M-CSF and GM-CSF in fostering placental growth, fetal growth, and fetal survival. Transplantation Proc. 21, 566-569.

Received 8 September 1989 